\title{
Diffusion-weighted magnetic resonance imaging: biomarker for treatment response in oncology*
}

\author{
Ressonância magnética com difusão: biomarcador de resposta terapêutica em oncologia \\ Maria Luiza Testa ${ }^{1}$, Rubens Chojniak $^{2}$, Letícia Silva Sene $^{3}$, Aline Santos Damascena ${ }^{4}$
}

\begin{abstract}
The authors report a case where a quantitative assessment of the apparent diffusion coefficient (ADC) of liver metastasis in a patient undergoing chemotherapy has shown to be an effective early marker for predicting therapeutic response, anticipating changes in tumor size. A lesion with lower initial ADC value and early increase in such value in the course of the treatment tends to present a better therapeutic response.
\end{abstract}

Keywords: Magnetic resonance imaging; Diffusion; Liver metastases; Breast cancer; Chemotherapy; Therapy monitoring.

Resumo Relatamos um caso no qual a avaliação quantitativa do coeficiente de difusão aparente (ADC) de metástases hepáticas submetidas a quimioterapia se mostrou um bom preditor e marcador precoce de resposta terapêutica, antecipando alterações de tamanho. Lesão com valor inicial do ADC mais baixo e com aumento precoce deste valor no curso do tratamento tende a apresentar melhor resposta terapêutica tardia.

Unitermos: Ressonância magnética; Difusão; Metástases hepáticas; Câncer de mama; Quimioterapia; Monitoramento da terapia.

Testa ML, Chojniak R, Sene LS, Damascena AS. Diffusion-weighted magnetic resonance imaging: biomarker for treatment response in oncology. Radiol Bras. 2013 Mai/Jun;46(3):178-180.

\section{INTRODUCTION}

Breast cancer is the most common malignant tumor in women ${ }^{(\mathbf{1})}$. The Brazilian radiological literature has recently been very preoccupied with the role played by imaging methods in the improvement of the diagnosis of breast cancer ${ }^{(2-11)}$. Most patients with metastatic breast cancer will receive numerous antitumor therapies in an attempt to minimize symptoms and prolong life. The oncology objective is to individualize the patient care to improve the therapeutic responses $^{(\mathbf{1})}$. Thus, the availability of a tool for early monitoring of the therapeutic response is desirable, avoiding the treatment toxicity and unnecessary expenses.

* Study developed in the Department of Imaging Diagnosis at Hospital A. C. Camargo, São Paulo, SP, Brazil.

1. Master of Sciences - Oncology, MD, Radiologist, Hospital A. C. Camargo, São Paulo, SP, Brazil.

2. PhD, Director of Department of Imaging Diagnosis, Hospital A. C. Camargo, Professor, School of Medicine, Universidade Nove de Julho, São Paulo, SP, Brazil.

3. Fellow Master degree in Science - Oncology, MD, Radiologist, Hospital A. C. Camargo, São Paulo, SP, Brazil.

4. Statistics, Centro Internacional de Pesquisa (CIPE) Hospital A. C. Camargo, São Paulo, SP, Brazil.

Mailing Address: Dra. Maria Luiza Testa. Rua Professor Antônio Prudente, 211, Liberdade. São Paulo, SP, Brazil, 01509900. E-mail: mluizatesta@gmail.com.

Received August 23, 2012. Accepted after revision February $22,2013$.
The assessment of cancer and its metastases by means of functional imaging techniques may lead to a more reliable diagnosis and early knowledge of the treatment efficacy. Diffusion-weighted magnetic resonance imaging (MRI) represents a promising imaging tool for tissue characterization, prediction and evaluation of therapeutic response in oncology ${ }^{(\mathbf{1 2})}$. In cases of liver disease, diffusion-weighted imaging presents higher sensitivity in the detection of lesions as compared with T2weighted sequences ${ }^{(\mathbf{1 3})}$.

Diffusion-weighted MRI is a noninvasive imaging technique which measures the water mobility within the tissues ${ }^{(\mathbf{1}, 14)}$. The quantitative diffusion analysis is performed by means of the apparent diffusion coefficient (ADC), which is inversely proportional to the cellularity ${ }^{(\mathbf{1 4})}$. High ADC values correspond to greater freedom of motion of water molecules, for example, when some intact cell structures, such as membranes, are present. Processes such as cell apoptosis and proliferation influence the cell density and therefore the ADC value ${ }^{(\mathbf{1 2})}$.

Diffusion is a cell marker. Malignant lesions, such as liver metastases, frequently demonstrate low ADC values, except in cases of treated lesions or necrosis ${ }^{(15)}$. Low
ADC values (indicative of lesions with high cellularity) measured before the beginning of the treatment correspond to a subsequent good therapeutic response, indicating a greater decrease in tumor volume after chemotherapy ${ }^{(\mathbf{1 6})}$. Non significant changes in ADC were observed in lesions not responding to chemotherapy or in healthy liver parenchyma ${ }^{(16)}$. Pretreatment ADC values in tumors submitted to chemotherapy seem to be useful to evaluate the therapeutic response of liver metastasis ${ }^{(\mathbf{1 7})}$.

\section{CASE REPORT}

A female, 57-year-old patient from São Paulo, SP, Brazil, previously diagnosed with invasive breast ductal carcinoma and submitted to right mastectomy in May 2003, undergoing follow-up in the Department of Clinical Oncology of Hospital A. C. Camargo. In February 2011, imaging follow-up detected the presence of liver nodules, and biopsy demonstrated infiltration by carcinoma compatible with primary breast tumor, confirming the tumor relapse.

On March 22, 2011, conventional MRI demonstrated nodular liver lesions with a pattern of ring-shaped enhancement, suggesting involvement secondary to the 
baseline disease. All the lesions were assessed with diffusion-weighted MRI and ADC measurement. The two largest lesions presented $\mathrm{ADC}=1.6 \times 10^{-3} \mathrm{~mm}^{2} / \mathrm{s}$ each, and, in the other lesion, the ADC value corresponded to $0.6 \times 10^{-3} \mathrm{~mm}^{2} / \mathrm{s}$ (Figure 1). Chemotherapy (anti-HER2) was initiated in May 2011.

At the subsequent imaging evaluation on June 20, 2011, the lesions presented a significant increase in ADC, the two largest lesions with 2.2 and $2.3 \times 10^{-3} \mathrm{~mm}^{2} / \mathrm{s}$, and the third lesion with $\mathrm{ADC}=1.9 \times 10^{-3}$ $\mathrm{mm}^{2} / \mathrm{s}$ (Figure 2).

\section{DISCUSSION}

Patients with history of breast cancer are susceptible to develop liver metastasis in the course of the disease. Chemotherapy plays a relevant role in management and eradication of such lesions. However, the therapeutic response can hardly be predicted $^{(\mathbf{1})}$. With the use of diffusionweighted MRI, it can be observed that, in most tumors, an increase in the ADC value after the treatment initiation occurs in response to the therapeutics, reflecting the cell death induced by the treatment ${ }^{(\mathbf{1 2})}$.
Koh et al. have assessed 20 patients with 40 liver lesions by means of diffusionweighted MRI, before and after chemotherapy. After chemotherapy, the responsive lesions presented a significant increase in ADC. Non significant changes were observed in the metastatic lesions not responding to chemotherapy. Such authors have concluded that a significant increase in ADC values was observed in the responsive metastatic lesions ${ }^{(\mathbf{1 8})}$.

In another study, Cui et al. have analyzed 87 liver metastases in 23 patients 38 lesions responded and 49 did not re-

Figure 1. Magnetic resonance of the liver - image acquired on March 22, 2011. Liver metastases visualized on diffusion-weighted sequence (at left) and respective apparent diffusion coefficient values on the ADC mapping (at right) previously to the chemotherapy initiation: lesion $1=1.6 \times 10^{-3}$ $\mathrm{mm}^{2} / \mathrm{s}$; lesion $2=1.6 \times 10^{-3}$ $\mathrm{mm}^{2} / \mathrm{s}$; lesion $3=0.6 \times 10^{-3}$ $\mathrm{mm}^{2} / \mathrm{s}$.

Figure 2. Magnetic resonance imaging of the liver - image acquired on June 20, 2011. Liver metastases with respective apparent diffusion coefficient values on the ADC mapping, after about one month of chemotherapy: A: lesion $1=2.2 \times 10^{-3} \mathrm{~mm}^{2} / \mathrm{s}$; lesion $2=$ $2.3 \times 10^{-3} \mathrm{~mm}^{2} / \mathrm{s}$. B: lesion $3=$ $1.9 \times 10^{-3} \mathrm{~mm}^{2} / \mathrm{s}$. A significant increase in ADC values is observed.
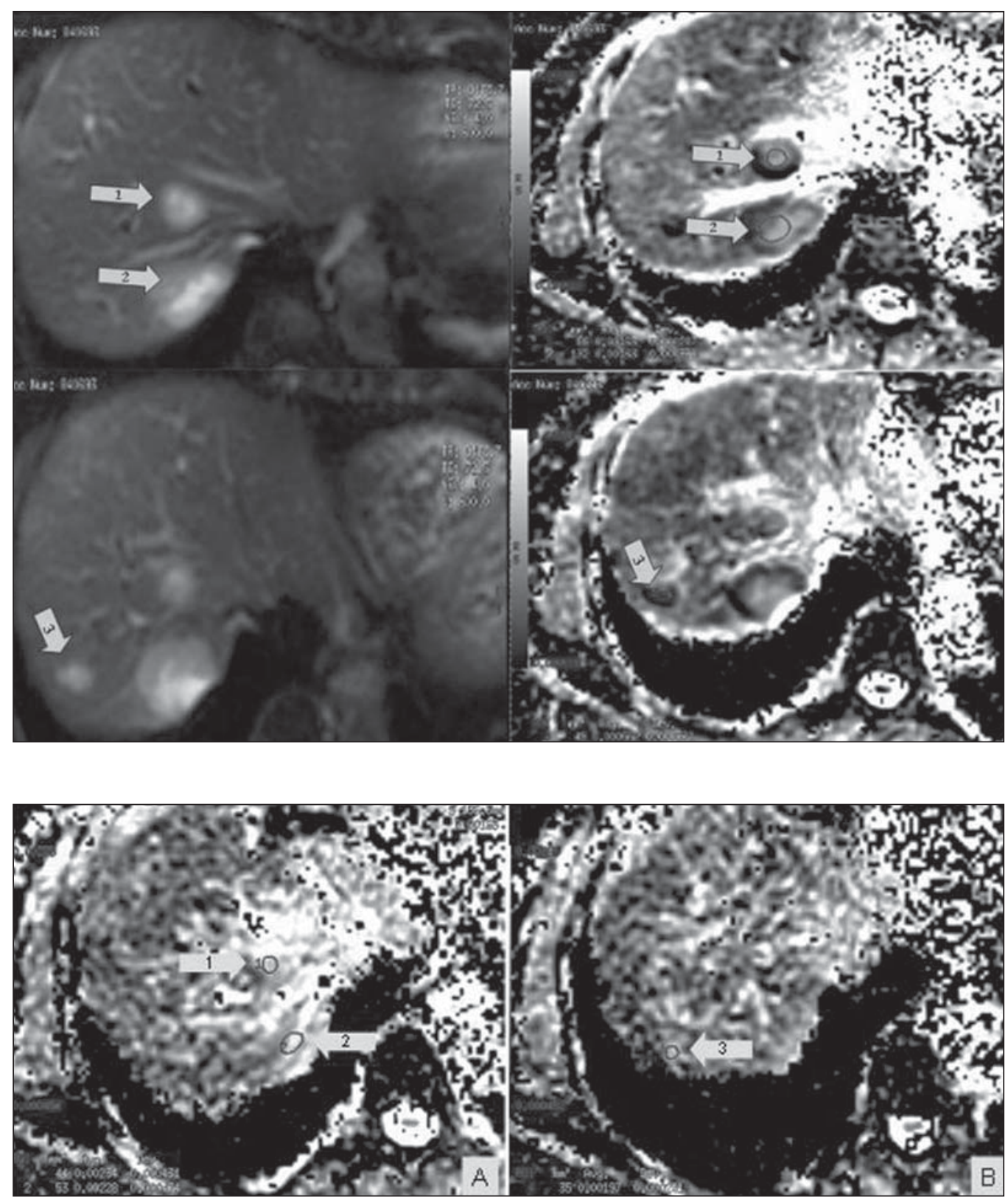
spond to chemotherapy. An early increase in ADC values was observed in the responsive lesions $(p=0.002)$. A statistically significant correlation was found between the decrease in the tumor size and the pretreatment ADC value $(p=0.006)$, besides early changes in the ADC $(p<0.001)^{(\mathbf{1 9})}$.

In the presently described case, chemotherapy was initiated as soon as it was evidenced that the liver lesions were suggestive of involvement secondary to the base disease, and after follow-up with diffusionweighted MRI. The lesions detected at the first follow-up study demonstrated early, significant increase in ADC, within about one month of treatment (seven-cycle chemotherapy).

Tumors are highly heterogeneous in terms of morphology, physiology (blood flow and vascular permeability) and genetic expression levels. Such variations in the tumor tissue may significantly regulate the therapeutic interventions efficacy. Because of the excellent imaging resolution and quantification provided by diffusionweighted MRI, it can be utilized as guidance in the early phases of the treatment, with basis on the different regions where there is response or resistance to the therapy. For example, in an individual submitted to chemotherapy for a primitive neuroectodermal tumor, the mean diffusion values for the anterior and posterior regions of the tumor were measured in a determined period. The anterior region demonstrated a significant increase in the diffusion values during the first three weeks of treatment, as compared with the posterior region of the tumor, indicating that the treatment was less effective in this region. In fact, 14 weeks later, the tumor had progressed in the posterior region, revealing that such region was probably resistant to the chemotherapy. The use of diffusionweighted in the follow-up of regional changes in tumors like the one described in the present case is potentially useful to guide the treatment. It is expected that such method can provide an early evidence of the therapeutic efficacy, before the treatment is completed, offering an additional parameter to evaluate the response for continuing or changing the treatment in case of ineffectiveness ${ }^{(\mathbf{2 0})}$.

Because of molecular and cell changes induced by the treatment which precede macroscopic changes such as, for example, in tumor size, diffusion-weighted MRI can be utilized to detect early changes in the lesion structure, thus allowing the use of such imaging marker as an indicator of early response in oncology. Additionally, the diffusion-weighted MRI technique allows a noninvasive evaluation of response on anatomical regions or histological subtypes, or after new molecular therapies which have not been accessible with conventional radiological methods ${ }^{(14)}$.

\section{CONCLUSION}

Changes in ADC may occur in lesions submitted to chemotherapy, before changes in the lesion size can be perceived, thus allowing that therapeutic decisions can be made in advance. Diffusion-weighted MRI has shown to be a promising tool in the prediction of the tumor response and follow-up of oncological patients undergoing chemotherapy.

\section{REFERENCES}

1. Theilmann RJ, Borders R, Trouard TP, et al. Changes in water mobility measured by diffusion MRI predict response of metastatic breast cancer to chemotherapy. Neoplasia. 2004;6:831-7.

2. Miranda CMNR, Santos CJJ, Maranhão CPM, et al. A tomografia computadorizada multislice é ferramenta importante para o estadiamento e seguimento do câncer de mama? Radiol Bras. 2012;45:105-12.

3. Moreira BL, Lima ENP, Bitencourt AGV, et al. Metástase na mama originada de carcinoma ovariano: relato de caso e revisão da literatura. Radiol Bras. 2012;45:123-5.

4. Azevedo AC, Canella EO, Djahjah MCR, et al. Conduta das funcionárias de um hospital na adesão ao programa de prevenção do câncer de mama. Radiol Bras. 2012;45:215-8.

5. Barra FR, Barra RR, Barra Sobrinho A. Novos métodos funcionais na avaliação de lesões mamárias. Radiol Bras. 2012;45:340-4.
6. Urban LABD, Schaefer MB, Duarte DL, et al Recomendações do Colégio Brasileiro de Radiologia e Diagnóstico por Imagem, da Sociedade Brasileira de Mastologia e da Federação Brasileira das Associações de Ginecologia e Obstetrícia para rastreamento do câncer de mama por métodos de imagem. Radiol Bras. 2012;45:334-9.

7. Calas MJG, Alvarenga AV, Gutfilen B, et al. Avaliação de parâmetros morfométricos calculados a partir do contorno de lesões de mama em ultrassonografias na distinção das categorias do sistema BI-RADS. Radiol Bras. 2011;44:289-96.

8. Marques EF, Medeiros MLL, Souza JA, et al. Indicações de ressonância magnética das mamas em um centro de referência em oncologia. Radiol Bras. 2011;44:363-6.

9. Oliveira FGFT, Fonseca LMB, Koch HA. Responsabilidade civil do radiologista no diagnóstico do câncer de mama através do exame de mamografia. Radiol Bras. 2011;44:183-7.

10. Vianna AD, Gasparetto TD, Torres GC, et al. Cancerização de lóbulos: correlação de achados mamográficos e histológicos. Radiol Bras. 2011; 44:275-8.

11. Vieira SC, Silva JS, Madeira EB, et al. Hemangioma de mama simulando metástase no PET-CT. Radiol Bras. 2011;44:401-2.

12. Heijmen L, Ter Voert EE, Nagtegaal ID, et al. Diffusion-weighted MR imaging in liver metastases of colorectal cancer: reproducibility and biological validation. Eur Radiol. 2013;23:748-56.

13. Taouli B. Diffusion-weighted MR imaging for liver lesion characterization: a critical look. Radiology. 2012;262:378-80.

14. Hamstra DA, Rehemtulla A, Ross BD. Diffusion magnetic resonance imaging: a biomarker for treatment response in oncology. J Clin Oncol 2007;25:4104-9.

15. Taouli B, Koh DM. Diffusion-weighted MR imaging of the liver. Radiology. 2010;254:47-66.

16. Charles-Edwards EM, deSouza NM. Diffusionweighted magnetic resonance imaging and its application to cancer. Cancer Imaging. 2006;6:13543.

17. Kele PG, van der Jagt EJ. Diffusion weighted imaging in the liver. World J Gastroenterol. 2010;16: 1567-76.

18. Koh DM, Scurr E, Collins D, et al. Predicting response of colorectal hepatic metastasis: value of pretreatment apparent diffusion coefficients. AJR Am J Roentgenol. 2007;188:1001-8.

19. Cui Y, Zhang XP, Sun YS, et al. Apparent diffusion coefficient: potential imaging biomarker for prediction and early detection of response to chemotherapy in hepatic metastases. Radiology. 2008;248:894-900.

20. Ross BD, Rehemtulla A. Specialized techniques in cancer management: funcional imaging. In: DeVita Jr VT, Lawrence TS, Rosenberg AS, editors. DeVita, Hellman and Rosenberg's cancer: principles and practice of oncology. 8th ed. Philadelphia, PA: Lippincott; 2008; p. 733-46. 